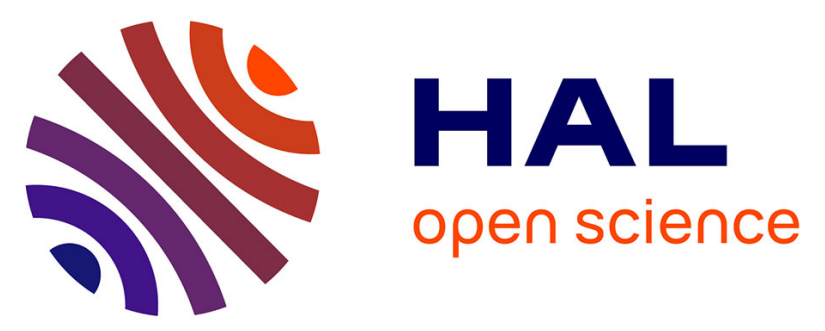

\title{
Effects of commercially-available acoustic alarms, designed to reduce small cetacean bycatch in gillnet fisheries, on the behaviour of North Sea fish species in a large tank
}

\author{
Ronald A. Kastelein, Sander van Der Heul, Jan van Der Veen, Willem C. \\ Verboom, Nancy Jennings, Dick de Haan, Peter Reijnders
}

\section{To cite this version:}

Ronald A. Kastelein, Sander van Der Heul, Jan van Der Veen, Willem C. Verboom, Nancy Jennings, et al.. Effects of commercially-available acoustic alarms, designed to reduce small cetacean bycatch in gillnet fisheries, on the behaviour of North Sea fish species in a large tank. Marine Environmental Research, 2007, 64 (2), pp.160. 10.1016/j.marenvres.2006.12.012 . hal-00501901

\section{HAL Id: hal-00501901 https://hal.science/hal-00501901}

Submitted on 13 Jul 2010

HAL is a multi-disciplinary open access archive for the deposit and dissemination of scientific research documents, whether they are published or not. The documents may come from teaching and research institutions in France or abroad, or from public or private research centers.
L'archive ouverte pluridisciplinaire HAL, est destinée au dépôt et à la diffusion de documents scientifiques de niveau recherche, publiés ou non, émanant des établissements d'enseignement et de recherche français ou étrangers, des laboratoires publics ou privés. 


\section{Accepted Manuscript}

Effects of commercially-available acoustic alarms, designed to reduce small cetacean bycatch in gillnet fisheries, on the behaviour of North Sea fish species in a large tank

Ronald A. Kastelein, Sander van der Heul, Jan van der Veen, Willem C. Verboom, Nancy Jennings, Dick de Haan, Peter Reijnders

PII: $\quad$ S0141-1136(07)00008-6

DOI: $\quad$ 10.1016/j.marenvres.2006.12.012

Reference: $\quad$ MERE 3093

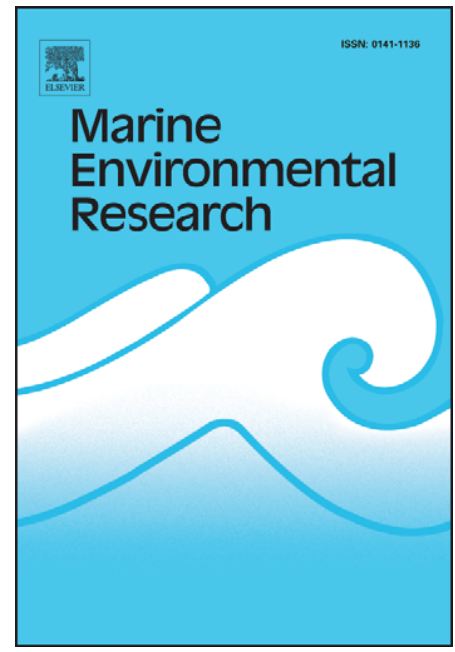

To appear in: $\quad$ Marine Environmental Research

Received Date: $\quad 24$ June 2006

Revised Date: 7 December 2006

Accepted Date: $\quad 15$ December 2006

Please cite this article as: Kastelein, R.A., van der Heul, S., van der Veen, J., Verboom, W.C., Jennings, N., de Haan, D., Reijnders, P., Effects of commercially-available acoustic alarms, designed to reduce small cetacean bycatch in gillnet fisheries, on the behaviour of North Sea fish species in a large tank, Marine Environmental Research (2007), doi: 10.1016/j.marenvres.2006.12.012

This is a PDF file of an unedited manuscript that has been accepted for publication. As a service to our customers we are providing this early version of the manuscript. The manuscript will undergo copyediting, typesetting, and review of the resulting proof before it is published in its final form. Please note that during the production process errors may be discovered which could affect the content, and all legal disclaimers that apply to the journal pertain. 
Effects of commercially-available acoustic alarms, designed to reduce small cetacean bycatch in gillnet fisheries, on the behaviour of North Sea fish species in a large tank

Ronald A. Kastelein ${ }^{a^{*}}$, Sander van der Heul ${ }^{\mathrm{a}}$, Jan van der Veen ${ }^{\mathrm{b}}$, Willem C. Verboom ${ }^{\mathrm{c}}$, Nancy Jennings ${ }^{\mathrm{d}}$, Dick de Haan ${ }^{\mathrm{e}}$, and Peter Reijnders ${ }^{\mathrm{f}}$

${ }^{a}$ Sea Mammal Research Company (SEAMARCO), Julianalaan 46, 3843 CC Harderwijk, The Netherlands

${ }^{b}$ Sea aquarium "Het Arsenaal”, Arsenaalplein 1, 4381 BL Vlissingen, The Netherlands

${ }^{c}$ TNO, P.O. Box 96864, 2509 JG The Hague, The Netherlands

${ }^{d}$ School of Biological Sciences, University of Bristol, Woodland Road, Bristol, BS8 $1 U G$, United Kingdom

${ }^{e}$ Wageningen IMARES (Institute for Marine Resources \& Ecosystem Studies), P.O. Box 68, 1970 AB IJmuiden, The Netherlands

${ }^{f}$ Wageningen IMARES (Institute for Marine Resources \& Ecosystem Studies), P.O. Box 167, 1790 AD Den Burg, Texel, The Netherlands

Received ....2005; received in revised form ...2006.

*Corresponding author. Tel.: + 31-341-45 62 52; fax: + 31-341-45 6732

E-mail address: researchteam@zonnet.nl (R.A. Kastelein) 


\section{Abstract}

World-wide many cetaceans drown incidentally in fishing nets. To reduce the unwanted bycatch in gillnets, pingers (acoustic alarms) have been developed that are attached to the nets. In the European Union, pingers will be made compulsory in some areas in 2005 and in others in 2007. However, pingers may effect non-target marine fauna such as fish. Therefore in this study, the effects of seven presently commercially-available pingers on the behaviour of five North Sea fish species in a large tank were quantified. The species tested were: sea bass (Dicentrarchus labrax), pout (Trisopterus luscus), thicklip mullet (Chelon labrosus), herring (Clupea harengus), and cod (Gadus morhua). The fish were housed as single-species schools of 9-13 individuals in a tank. The behaviour of fish in quiet periods was compared with their behaviour during periods with active pingers. The results varied both between pingers and between fish species. Sea bass decreased their speed in response to one pinger and swam closer to the surface in response to another. Thicklip mullet swam closer to the bottom in response to two pingers and increased their swimming speed in response to one pinger. Herring swam faster in response to one pinger, and pout and cod (close relatives) showed no behavioural responses to any of the pingers. Of the seven pingers tested, four elicited responses in at least one fish species, and three elicited no responses. Whether similar responses would be elicited in these fish species in the wild, and if so, whether such responses would influence the catch rate of fisheries, cannot be derived from the results of this study. However, the results indicate the need for field studies with pingers and fish. Based on the small number of fish species tested, the present study suggests that the higher the frequency of a pinger, the less likely it is to affect the behaviour of marine fish.

Key words: Acoustics; Cetaceans; Cod; Ecology, Herring; Noise pollution; Odontocetes; Pingers; Pout; Sea bass; thicklip mullet; Underwater sound.

\section{Introduction}

World-wide, every year, over 300,000 cetaceans are estimated to drown incidentally in fishing nets (Read et al., 2006). Many small odontocetes drown after accidental capture in gillnets (Lewison et al., 2004). One potential alternative to reducing the incidental bycatch of small odontocetes in gillnets by time and area closures of fisheries, change in fisheries practices, or by fish gear modifications, is to deter the animals from the nets acoustically. The presently commercially-available pingers used to do this produce sounds between 10 and 160 $\mathrm{kHz}$. Field studies with pingers on set gillnets have produced promising results with harbour porpoises (Phocoena phocoena; Lien et al., 1995; Kraus et al., 1997; Laake et al., 1998; Trippel et al., 1999; Gearin et al., 2000; Anonymous, 2000; Barlow and Cameron, 2003), and studies in captivity have shown that pingers elicit avoidance behaviour in porpoises (Kastelein et al., 1995; 1997; 2000; 2001). Behavioural studies in the field also show that porpoises avoid pingers (Laake et al., 1998; Culik et al., 2001). Although pinger use in gillnet fisheries is increasing, the long-term effects of pingers on porpoise bycatch and on non-target marine animals have not yet been studied.

One undesirable side-effect of pingers is local noise pollution, which may disturb marine fauna other than the species targeted. Knowledge of the ability of many marine animals to detect sound, and of the effects of sound on them, is limited. Marine animals are likely to be disturbed by anthropogenic noise in their environment, and intense sounds may cause negative physiological, auditory, and behavioural effects (Richardson et al., 1995). 
Sounds produced by pingers should reduce bycatch of odontocetes and perhaps other species, but should cause minimal noise pollution for other marine fauna.

The use of pingers will become widespread, as they become compulsory in some areas in 2005 and in others in 2007 for EU fishing vessels larger than $15 \mathrm{~m}$. Therefore, before pingers are widely used, their effects on marine animals, and especially fish, should be studied. Pingers developed to reduce odontocete bycatch should not deter the fisheries' target species from the gillnets, and should not deter target or non-target fish from ecologically important areas such as feeding and breeding grounds, or mask their communication sounds.

In some field studies on the effects of pingers on odontocetes, the size of the fish catch in nets with and without pingers has been compared. The effects of pingers on fish [Clupeids, cod (Gadus morhua) and Chinook salmon (Oncorhynchus tshawytscha)] in pens and tanks have also been investigated. Only one study suggests a reduction in catch rate of the target fish species. All other studies showed no effect on catch rate or on the behaviour of the fish in a pen or tank (Table 1).

Fish use sound for a variety of functions including hunting, territorial behaviour, bonding, spatial orientation, predator detection, and escape. Most audiograms of marine fish species indicate that their best sensitivity to sounds is within the $100 \mathrm{~Hz}-2 \mathrm{kHz}$ range. This narrow bandwidth of hearing sensitivity could be due to mechanical limitations of the sense organs (Astrup and Møhl, 1993, 1998; Motomatsu et al., 1998; Mann et al., 1997, 1998, 2001; 2005; Akamatsu et al., 1996, 2003; Anraku et al., 1998). Some researchers have investigated the effects of sounds on the behaviour of marine fish (Moulton and Backus, 1955; Blaxter et al., 1981; Blaxter and Hoss, 1981; Fuiman et al., 1999; Enger et al., 1993; Knudsen et al., 1994; Luczkovich et al., 2000; Finneran et al., 2000; Lagardère et al., 1994 ; Løkkeborg and Soldal, 1993; Engås et al., 1996; Pearson et al., 1992; Skalski et al., 1992; Hawkins, 1986; Popper and Carlson, 1998; Wahlberg and Westerberg, 2005).

The sounds made by commercially-available pingers differ from the sounds used in previous studies on the effects of sound on fish. Therefore the aim of the present study was to determine whether commercially-available pingers, designed to deter small cetaceans from gillnets, have any effect on the behaviour of certain North Sea fish species under controlled conditions in a tank.

\section{Materials and methods}

\subsection{Study animals}

Five fish species regularly occurring in the North Sea were selected for testing based on their availability, their ease of maintenance in captivity, the temperatures at which they can be kept (the water temperature in the tank was influenced by the air temperature of the environment), and their economic importance in fisheries. In addition, the animal welfare commission of the Netherlands government stipulated that the individual fish used had to feed readily in captivity, so they had to come from aquaria.

A school of 9-13 individuals of each species was placed in a tank. The sea bass (Dicentrarchus labrax), pout (also called bib, or pout whiting in the US; Trisopterus luscus), thicklip mullet (Chelon labrosus), and cod (Gadus morhua) were supplied by "Het Arsenaal Aquarium", Vlissingen, and the herring (Clupea harengus) by the Oceanium department of "Blijdorp Zoo", Rotterdam. Characteristics of the fish are shown in Table 2. The fish had been wild-caught by hook and line or in a trap, so that damage to their swim bladder, which may be involved in hearing in some fish species, was unlikely. The fish used in this study were all adapted to captivity and were feeding voluntarily. Except for herring, the fish were 
fed $a d$ lib. on pieces of raw fish (food was given until the animals stopped eating) twice a week, after the daily study sessions. Herring were fed ad lib. on pellets (Troutvit, size 00; Nutreco Aquaculture) once a day, after the study sessions.

\subsection{Study area}

The experiments were conducted in an outdoor tank at the field station of the Netherlands National Institute for Coastal and Marine Management (RIKZ) at Jacobahaven, Zeeland, the Netherlands. The freestanding rectangular tank ( $7.0 \mathrm{~m}$ long, $4.0 \mathrm{~m}$ wide; water depth: $2.0 \mathrm{~m})$ was made of plywood covered on both sides with fibreglass (Fig. 1). A layer of $3 \mathrm{~cm}$ thick hard-pressed Styrofoam was placed between the bottom of the tank and the concrete floor, to reduce contact noise from the environment in the pool. The pool walls were blue (Ral colour $50 / 15)$. Red gridlines $(1.5 \mathrm{~cm}$ wide) were taped on the walls and bottom of the tank at $0.5 \mathrm{~m}$ intervals in the vertical direction and at $1 \mathrm{~m}$ intervals in the horizontal direction.

To reduce predation by birds, algal growth, impact of noise from rain, glistening of the water surface, and to create a more even light pattern in the pool, a blue tarpaulin canopy was suspended at an angle above the water surface $(1.5 \mathrm{~m}$ on one side and $0.75 \mathrm{~m}$ on the other side).

Scaffolding surrounded the pool for easy access, but made no contact with the pool. Two research cabins were placed on one side of the scaffolding: one to house the video recording equipment and sound generation equipment, and one to house the sound calibration equipment.

The water was pumped directly from the nearby Oosterschelde (a North Sea estuary in the SW coast of the Netherlands). The salinity was 30-33\%o, the $\mathrm{pH}$ 7.9-8.1, nitrogen concentration $<5 \mathrm{mg} / 1 \mathrm{~N}$, and nitrate concentration $<0.1 \mathrm{mg} / \mathrm{l}$. To ensure the good water clarity needed to film the fish, the water was circulated via sand and carbon filters and UV light. During the experiments the water system was a closed circuit for the period in which each fish species was tested (about 5 weeks). Water parameters (temperature, salinity, oxygen, and nitrate) were measured daily and remained well within the boundaries suitable for the fish. The water temperature varied during the study period due to fluctuations in the air temperature. During the test period with the sea bass, the water was heated to keep it above 4 ${ }^{\circ} \mathrm{C}$, so that the fish showed normal swimming behaviour (Table 3).

The week before each species was tested, the fish were kept in a white polyester $2.2 \mathrm{~m}$ diameter holding tank with a water depth of $1 \mathrm{~m}$. The tank stood next to the test tank and contained the same water composition at the same temperature as the test tank.

To make the environment inside the tank as quiet as possible, the filter unit had a lownoise pump. To reduce contact noise entering the pool, the pump and filter unit were placed on rubber tiles. To reduce contact noise, flexible tubes were used to connect the filtration pump to the pool.

As the pump in the pool was extremely quiet, it was left on during the experiments, so as not to change the ambient noise before and during the test periods. The background noise level in the pool is shown in Figure 2. To maintain sufficient light for the underwater cameras, two lamps (2000 Watts each) were lit $30 \mathrm{~cm}$ above the water surface. The lamps were switched on at least half an hour before a session began and were only used when required to obtain good video images (during an entire session they were either on or off).

\subsection{Stimuli}

In order to identify the behavioural parameters which indicated a response for each fish species, the individuals of each species were first submitted to sounds that were known to 
have an effect on them (the 'known effect' sounds). A $600 \mathrm{~Hz}$ tone pulse produced clearly visible responses in all species except herring and cod. For herring, a $3 \mathrm{kHz}$ tone pulse was used (for specifics of the signals see Table 4). For cod, no response could be elicited to any sound that could be produced with the available equipment, though loud $300 \mathrm{~ms}$ duration sounds in a wide frequency range $(50 \mathrm{~Hz}-60 \mathrm{kHz})$ were offered. The sounds were produced by a generator (Hewlett Packard, model 33120A), a power amplifier (Quad 150), an impedance matching transformer, and an underwater transducer (Ocean Engineering Enterprise, model DRS-8; $20 \mathrm{~cm}$ diameter).

Once the behavioural parameters that indicated a response had been identified for each fish species, the effect of seven commercially-available pingers on the behaviour of the five fish species was quantified by comparing the parameters during baseline periods (pinger off) with those during test periods (pinger on). Although the reaction of fish to sounds may be spectrum-dependant (Nestler et al., 1992), the fish responded to the pingers in the same way as they had to the 'known effect' sounds.

The pingers were suspended from ropes $20 \mathrm{~cm}$ from the pool wall, and were positioned horizontally at $1 \mathrm{~m}$ below the water surface, half way up the water column (Fig. 1). A weight of $150 \mathrm{~g}$ underneath each pinger kept it at the right depth. To avoid influencing the behaviour of the fish by human action, each pinger was modified so that it could be activated remotely from inside the research cabin.

During test sessions sounds were monitored by use of a hydrophone (Labforce $1 \mathrm{BV}$, model 90.02.01), a custom made pre-amplifier, and an amplified loudspeaker. For sounds above $16 \mathrm{kHz}$, the hydrophone was connected to a heterodyne bat detector (Stag Electronics, UK, model Batbox III) to make the signal audible to the researchers.

\subsection{Sound parameters and Sound Pressure Level distribution in the tank}

In order to measure the Sound Pressure Levels (SPLs) fish had been exposed to, the SPLs of all sound sources were measured at distances of 1 and $6 \mathrm{~m}$ from the sound source at the depth of the pinger/transducer. Sounds were measured with a hydrophone (Brüel \& Kjaer $(\mathrm{B} \& \mathrm{~K})$, model 8101$)$ connected to a battery-powered conditioning amplifier (B\&K, model Nexus 2690). The output was connected, via a coaxial module (National Instruments, model BNC-2090), to a computer (Joheco, PIV-1.6 GHz) with a data acquisition card (National Instruments, model PCI-MIO-16E-1), on which signals were digitised with a sample frequency of $512 \mathrm{kHz}$ and 12-bits resolution. A pistonphone (B\&K, model 4223) was used as a reference to calibrate the system. Monitoring, recording and analysis of sounds were accomplished by the use of software modules developed by IMARES (in National Instruments, Labview 6.0).

The sound sources and their measured acoustic properties are shown in Table 4. The Source Levels (SLs) of the pingers are shown as $\mathrm{SL}_{\text {pulse }}$ which is the signal level fast Fourier transformed (FFT) over the duration of the signal according the formulae:

$s p l_{r m s}=10 \log \left(\frac{1}{T} \int_{0}^{T} \frac{p(t)^{2}}{p_{0}^{2}} d t\right)$

In which $s p l$ is Sound Pressure Level, rms is root-mean-square, $\mathrm{T}$ is time, $\mathrm{p}$ is pressure, $\mathrm{p}_{0}$ is the reference pressure, and $\mathrm{dt}$ is the time window. To compare the levels of pinger signals with constant time intervals to those with randomized repetition rates, the levels of all signals measured at $1 \mathrm{~m}$ distance are also integrated in FFT over the time of a complete cycle (time between two rise times), this level is called $\mathrm{SL}_{\text {cycle }}$ (also known as $\mathrm{L}_{\mathrm{eq}}$ ). For randomized signals the $\mathrm{SL}_{\text {cycle }}$ is calculated over the shortest, average and longest repetition rate. The 
results of the randomised signals are based on file lengths of $195 \mathrm{~s}$ and therefore may not be representative for the timing over longer time periods, such as during the test sessions.

A Dukane NetMark 1000 pinger was used as a reference to validate the SPL measurements of sound sources at $1 \mathrm{~m}$ distance. The measured SL in the tank with the hydrophone at $1 \mathrm{~m}$ from the pinger deviated by approximately $2 \mathrm{~dB}$ from the calculated SL of the same pinger based on a measurement in open sea with the hydrophone $2 \mathrm{~m}$ from the pinger. Recordings of the SaveWave black high impact and white high impact pingers were also compared with those of the same pingers measured at sea. These levels matched within 3 $\mathrm{dB}$.

The SPLs measured at $6 \mathrm{~m}$ from the source demonstrate the contribution of the reverberant effects of the sound in the tank and showed that the sound propagation loss did not follow the formula SPL $=\mathrm{SL}-[20 \log \mathrm{R}]$, in which $\mathrm{R}$ is the distance in $\mathrm{m}$ between the sound emitter and the recording hydrophone. In fact, the SPL and pulse duration of the sound sources hardly decreased with distance from the transducer. The 'sweep pingers' (SaveWave and AQUAmark) all produced low frequency components in the range of $0.5-5 \mathrm{kHz}$, with peaks 30-40 dB above the system noise level. The $10 \mathrm{kHz}$ tonal pingers (Fumunda and Airmar) did not produce these low frequency components.

\subsection{Observation equipment}

The behaviour of the fish was recorded by three black-and-white underwater video cameras (Mariscope, model Micro). The cameras were mounted in a row along one side of the pool (Fig. 1), at a depth of $1 \mathrm{~m}$, so that about $60 \%$ of the water volume was in view.

\subsection{Methodology}

In each test a school of fish of only one fish species was used, in order to avoid the behaviour of one species influencing the behaviour of another. The $9-13$ fish of each species were placed in the tank at least three days before the first session was conducted, to allow the fish to habituate to the tank. The pinger (or transducer for 'known effect' sounds) was placed in the pool at least one hour before a session. Each session consisted of a 10-minute baseline period during which no sound was produced, followed immediately by a 10-minute test period during which the pingers were active or the 'known-effect' sound was produced.

Each day, four sessions of 20 minutes each were conducted (at 08.30, 10.00, 11.30, and $13.00 \mathrm{~h}$ ). Each session a different pinger was used in random order. Per fish species, each pinger was tested up to 11 times over a period of around five weeks. The study was conducted between November 2003 and July 2004.

\subsection{Analyses of video recordings}

Behavioural parameters were measured from the video recordings. The images from the three cameras were synchronized by means of a marker signal which was produced every minute from a tape recorder in the research cabin and recorded on the audio tracks of the video recorders. A scan sampling technique was used: at the end of each minute during the 10 minute recording period, the tape was stopped and the image was analysed. From each camera image, only the behaviour of fish in a specific section of the tank (the boundary of which was determined by the grid on the pool wall) was analysed. Because the three images overlapped somewhat, this method ensured that each individual fish was recorded only once per scan moment. Fish behaviour was only measured where it could be quantified accurately, in approximately a quarter of the volume of the tank. That meant that the behaviour of the 
fish was only scan-sampled when they were in the $1 \mathrm{~m}$ section of the wall opposite the cameras (Fig. 1), and swimming parallel to the wall (so that location and swimming speed could be measured accurately). All distance parameters were determined with $10 \mathrm{~cm}$ accuracy. A fourth aerial camera with a wide angle lens, placed in front of the window on one end of the pool, provided a general view of how the fish swam in the tank. Images from this camera showed that none of the fish species tended to swim near the underwater cameras.

The following response parameters were derived from the video footage:

1. School length. The distance between the fish closest to the pinger or transducer and the one furthest away. Reasoning: fish may school tighter when feeling threatened.

2. Distance to bottom. Distance between the centre of each fish and the bottom of the tank (range: 0.1-2.0 m). Reasoning: fish may drop to the bottom when feeling threatened.

3. School height. The distance between the fish closest to the bottom and the one furthest away from it. Reasoning: fish may school tighter when feeling threatened.

4. Swimming speed. The speed of each fish was determined by measuring the time (by stopwatch) it took to swim $1 \mathrm{~m}$ (from one vertical line on the wall to the next) after the scan signal. If fish were swimming in a school, all fish were given the same speed. If the distance between a fish and the school was more than $0.5 \mathrm{~m}$, its speed was measured separately. Reasoning: fish may speed up when feeling threatened.

5. Polarisation in the school. The proportion of a group of fish in the view of a camera swimming in the same direction. Fish with swimming directions differing less than 90 degrees were defined as swimming in the same direction. Reasoning: fish may increase polarisation when feeling threatened.

\subsection{Statistical analysis}

Per scan moment, the mean of all parameters of all visible fish (total of all recordings of the three cameras) was taken, and then the mean for each baseline or test period ( $\mathrm{n}=10$ for each period; one scan moment per minute during the 10-minute period) was used for the analysis.

The difference in the mean variables between baseline and test (calculated as test minus baseline) was compared to zero in paired statistical tests. The response to the 'known effect' sound was first considered for each species. Paired t-tests, or if the differences were not normally distributed, Wilcoxon matched pair tests (Zar 1984), were used to evaluate the effect of the sounds on the behavioural parameters. From the results of these tests, for each species, response parameters were identified, which were defined as those which showed a significant $(\alpha=0.05)$ response to the 'known effect' sounds. Only these response parameters, which differed for each fish species, were compared in baseline and test periods with the pingers. Paired t-tests or Wilcoxon matched pair tests, as appropriate, were used as described above. Statistical tests were carried out using Minitab release 13 (Ryan and Joiner 1994) and were all two-tailed.

\section{Results}

\subsection{General swimming behaviour and effects of "known effect" sounds on each fish species}

The general behaviour of the five fish species used in the present study differed (Table 5). Results of the statistical tests on all measured parameters showed that responses to the 'known effect' sounds also varied between species. Sea bass and thicklip mullet responded by 
increasing their speed and swimming closer to the bottom, herring by increasing their speed, and pout by swimming closer to the bottom (Table 6). No response at all could be elicited in cod, although several sounds that were certainly audible to them (Buerkle, 1967; Chapman and Hawkins, 1973; Offutt, 1974), and some at higher frequencies, were tried. No species responded to 'known effect' sounds by increasing the school length or height, or by increasing the polarisation in the school. The behavioural parameters that did change during sound emissions were thus identified for each species, and were measured and compared in the tests with the pingers.

\subsection{Effects of pingers on each fish species}

Sea bass responded to the AQUAmark 100 and Fumunda pingers, but opposite to their response to the 'known effect' sound. They swam more slowly when the AQUAmark 100 pinger was active and swam closer to the water surface when exposed to the sound of the Fumunda pinger (Fig. 3(a) and (b)). Thicklip mullet reacted to the Airmar pinger by increasing speed, and to the AQUAmark 100 and SaveWave white high impact pingers by swimming closer to the bottom (Fig. 3 (c), (d) and (e)). Herring reacted to the Airmar pinger by increasing speed. Cod and pout did not respond in any way to any pinger, and although for cod, in the absence of 'known effect' parameters, all six recorded behavioural parameters were tested, no significant differences between baseline and test were found. No reactions were observed in any of the five fish species to the AQUAmark 200, the SaveWave endurance and SaveWave black high impact pingers (Table 6).

\section{Discussion and conclusions}

\subsection{Evaluation of the observations}

Of the five behavioural parameters recorded, only swimming speed and distance to bottom formed part of the response to pingers and 'known effect' sounds. The fish species did not respond to the pingers or 'known effect' sounds by swimming closer together (horizontally or vertically) or by increasing the polarisation of the school. As this is a pilot study, it was important to test all available pingers, and also, given the potential variability in response, to quantify many different behavioural parameters. In follow-up studies in similar contexts, emphasis can be placed on the behavioural parameters shown to be affected in the present study.

In fisheries, pingers are attached to gillnets. Fish that are about to be caught in the nets are close to the pingers, and are therefore exposed to sound levels similar to those experienced by the fish in the present study. So, the responses observed in the fish species in the present study may be observed in the wild in fish near nets (at $<6 \mathrm{~m}$ distance). Whether the use of pingers will cause a drop in catch rate cannot be predicted from the present study. Responses may be influenced by environmental parameters such as location, water depth (pressure), time of day, and water temperature, and may depend on the animal's behaviour, physiological condition, and motivational condition. Responses are also influenced by the surrounding fauna (conspecifics, prey or predators).

In the rectangular tank, resonance enhanced specific components of the projected sound. Because gillnet fishery in the North Sea is usually carried out in shallow water or near wrecks, resonant effects between the bottom and the water surface may also occur at sea (although less than in a tank). 
The size of a tank has an influence on the general swimming behaviour of many fish species. The fish swam very slowly or not at all in the small holding tank ( $2.2 \mathrm{~m}$ diameter, 1 $m$ deep). In the large test tank, they were much more active. So, although the test tank was far from a natural environment, it may be a much better study area than the smaller tanks that have been used in several previous studies on the effects of sound on fish.

This experiment was not designed to test whether fish move away from the sound. In the confines of the tank, the sound did not attenuate as it would have done at sea, so a larger tank (or better a floating pen) would have been needed to test for movement away from the sound. In fact, the SPL measurements showed that due to the reverberant field, the sound in the tank did not attenuate over distance. The SPL differed per location because of resonance, but did not vary in relation to the sound source. Therefore, a response consisting of a move away from the sound source was not expected in the present study based on an SPL gradient. In addition, moving away from a sound source requires directional hearing, which these fish may or may not possess. Furthermore, the loss in exposure level by moving away from a sound source in the sea is very small if the fish is not very close to the sound source. For example, moving from 10 to $11 \mathrm{~m}$ away from a sound source will only reduce exposure level by less than $1 \mathrm{~dB}$ and the fish must move to $20 \mathrm{~m}$ to reduce the received level with $6 \mathrm{~dB}$. Moving up or down the water column may provide a much larger reduction in exposure level as the fish could move into an acoustic shadow zone.

\subsection{Potential causes of differences in behavioural responses to pingers}

The effect of a pinger may depend on properties of the sound, such as frequency spectrum, duration, repetition rate, background noise (acoustic interference, masking), SPL (exposure level) and spectrum received by the animal, and exposure duration, as well as properties of the animal, such as hearing properties (sensitivity, critical ratio and receiving beam pattern), and species-specific or individual behavioural reactions to sound. The reactions of the fish in the present study to the 'known effect' signals could be described as startle responses, whereas the animals' responses to some of the pingers were slow and more subtle. The exposure level to a sound may also influence the direction of a reaction. Low exposure level sounds can be attractive, whereas the same sounds can be deterrent at higher exposure levels. Signal duration also plays a role in the effect of a sound on fish; a $500 \mathrm{~ms}$ pulse length provides adequate time for fish to detect and react to a sound (Hawkins, 1981; Nestler et al., 1992; Dunning et al., 1992).

Three fish species in the present study reacted to one or more of four of the seven pingers tested. There are many acoustic differences between the pingers, so it is difficult to determine which acoustical parameter caused the behavioural effect in a particular fish species. However, thicklip mullet and sea bass reacted to the AQUAmark 100 and not to the AQUAmark 200. Most parameters of both pingers were similar, but the source level of the AQUAmark 100 was around $14 \mathrm{~dB}$ higher than that of the AQUAmark 200. Although the Fumunda and Airmar both produce a low frequency (LF) fundamental frequency around 10 $\mathrm{kHz}$, the Fumunda had more energy in harmonics (Table 4). Herring and thicklip mullet reacted only to the Airmar pinger, while sea bass reacted only to the Fumunda pinger. It is possible that differences in the orientation of sound beams between the two pingers, or in the hearing sensitivity of the species, caused them to react differently to the two similar pingers. The Airmar pinger contains air, which causes some directional effects. The directionality was not checked for this study, but the pingers were in a horizontal position, as they would be if used in fisheries. In a previous study, herring did not react to a Dukane NetMark 1000 pinger (Wilson and Dill, 2002), which is designed to be equivalent to the Airmar and Fumunda pingers used in the present study. These pingers are compulsory in some US gillnet fisheries 
for part of the year. In the present study, the herring increased their swimming speed when subjected to the sounds of the Airmar pinger, which produced less harmonic energy than the Fumunda and Dukane NetMark 1000 pingers. The sweep pingers (AQUAmark 100 and 200 and SaveWave) produced energy in the $0.5-5 \mathrm{kHz}$ frequency range, and it is possible that the fish reacted to these low frequency components of the spectrum.

Thicklip mullet reacted to the SaveWave white high impact pinger but not to the other two SaveWave pingers. This could be because the level of the SaveWave white high impact pinger was around $15 \mathrm{~dB}$ higher than that of the SaveWave endurance pinger or because its spectrum was lower in frequency than that of the other two SaveWave pingers. Because the duration of the pulse and the repetition rate of the SaveWave endurance pinger were proportional, the $S L_{\text {cycle }}$ levels of the minimum cycle were equal to the levels measured over the maximum cycle and also much lower than those of the other two SaveWave pingers (-10 dB) (Table 4).

In some cases the sound characteristics measured for this study differed from the manufacturer's specification. The SL of the SaveWave pingers were $10 \mathrm{~dB}$ lower than the SL specified by the manufacturer, while the SL of the Fumunda pinger was $10 \mathrm{~dB}$ above the specified SL. The pulse duration of the Fumunda pinger was $300 \mathrm{~ms}$ instead of the specified $400 \mathrm{~ms}$. The SL of the AQUAmark 100 pinger was $10 \mathrm{~dB}$ above the specified SL, while the AQUAmark 200 pinger was $10 \mathrm{~dB}$ below the specified SL.

Information on hearing sensitivity is available for sea bass (J. Lovell in Nedwell et al., 2004), herring (Enger, 1967; Blaxter and Hoss, 1981; Blaxter et al., 1981; Schwarz and Greer, 1984; Mann et al., 2005) and cod (Enger and Andersen, 1967; Chapman and Hawkins, 1973; Offutt, 1974; Buerkle, 1967; Astrup and Møhl, 1993; Astrup and Møhl, 1998), but not for pout and thicklip mullet. Based on the audiograms, the frequency spectrum $(>9.8 \mathrm{kHz})$, and the exposure levels in the tank (up to around $135 \mathrm{~dB}$ re 1 re $1 \mu \mathrm{Pa}$ ), the pingers should not have been audible to sea bass and cod, and to Atlantic herring if its hearing resembles that of Pacific herring (Mann et al., 2005). However, only the cod did not respond to the pingers.

\subsection{Suitability of the pingers for use in gillnet fisheries}

The results of the present study cannot be extrapolated to the remaining approximately 155 North Sea fish species. The reactions of fish to pinger sounds were observed in quiet conditions in a tank. In the wild, the sound characteristics that caused the fish to react in the tank may be masked by background noise. Whether responses similar to those observed in the present study would be elicited in the fish species in the wild, and if so, whether such responses would influence the catch rate in fisheries, cannot be predicted based on the results of the present study. However, even if pingers do not affect the catch of the target fish species in the fisheries, pinger sounds should be selected that do not affect other fish (and other marine fauna) in the environment.

Both the frequency spectrum and SL played a role in the effect of the pingers on the fish species tested. A combination of a SL $<130 \mathrm{~dB}$ re $1 \mu \mathrm{Pa} @ 1 \mathrm{~m}$ and a high frequency spectrum $(>10 \mathrm{kHz}$, although more knowledge on the hearing sensitivity of fish species is needed to verify this figure) seems to reduce the chance of a pinger affecting the behaviour of fish. However, reducing the SL may make the pinger less effective at reducing porpoise bycatch, especially under high background noise levels. A compromise may be needed. There are other considerations for a choice of sound characteristics apart from the effect of pingers on porpoises and fish. For instance, signals above $70 \mathrm{kHz}$ cannot be heard by pinnipeds, and thus cannot act as a "dinner bell" for these animals which can damage the catch and the gillnets. 


\subsection{Suggestions for further research}

The main limitations of the present study are that only about $3 \%$ of the fish species that occur in the North Sea were tested, and that if a pinger with new acoustic characteristics is developed, a completely new study would be needed to test its effect on fish. Therefore, it would be useful to conduct a fundamental study on the reaction of various fish species to a wide range of sounds. For instance, effects of pure tones, narrow and wide-band sweeps, noise bands in the $100 \mathrm{~Hz}-180 \mathrm{kHz}$ frequency range, and sounds of biological relevance could be tested. To determine the effects of the low frequencies which were present in sweep signals, a trained (feeding) experiment with high frequency (HF) sounds with and without LF contribution could be useful. With this information, the impact of any sound could be predicted, and for fish species of high commercial, scientific or public interest, audiograms could be obtained in follow-up studies. Despite important steps being made towards understanding effects of sounds on fish, comparisons of actual catches in nets with and without pingers are still needed to measure the effect of pingers on fisheries.

\section{Acknowledgements}

We thank Rob Triesscheijn for all his help, Petra van der Marel, Sonja de Wilde, Natascha Lor and Marius van Vliet for their help in data acquisition and animal husbandry. We thank Gerard Visser, Michaël Laterveer, and Peter van Putten (all of the Oceanium department of Blijdorp Zoo, Rotterdam), for lending us the herring and for transporting the herring to the study site. We thank Gijs Rutjes (Coppens International) for providing some of the sea bass. We thank Amy Scholik (GMI, USA) for all her help and advice, and Jacob Tougaard (National Environmental Research Institute, Denmark), David Mann (University of South Florida, USA), Ben Wilson (Marine Mammal Research Unit, Fisheries Centre, Canada), and Frank Reier Knudsen (Simrad AS, Norway) for their constructive comments on the manuscript. The following representatives of the companies that provided the pingers for this project also gave valuable constructive comments on the manuscript: Andy Smerdon and Richard Love (Aquatec Sub Sea Ltd, UK), Rick van Lent (SaveWave B.V., The Netherlands), Steve Christensen (Airmar Technology Corporation), and Stan Pleskunas (Fumunda Marine Products). Facilities at the research station were made available thanks to Dick Vethaak (RIKZ), Roeland Allewijn (RIKZ), and Wanda Zevenboom (Netherlands North Sea Directorate). This project complied with the Dutch standards for animal experiments. The project was funded by the Netherlands Ministry for Agriculture, Nature, and Food Quality (DWK-program 418: North Sea and Coast), and supervised by IMARES-Texel, The Netherlands (Han Lindeboom).

\section{References}

Akamatsu, T., Matsusita, Y., Hatakeyama, Y. \& Inoue, Y. (1996). Startle response level of the Japanese anchovy Engraulis japonicus to underwater pure tone signals. Fisheries Science 62, 648-649.

Akamatsu, T., Nanami, A., \& Yan, H.Y. (2003). Spotlined sardine Sardinops melanostictus listens to 1-kHz sound by using its gas bladder. Fisheries Science 69, 348-354.

Anonymous (2000). Annex I, Report of the Sub-Committee on Small Cetaceans. Journal of Cetacean Research Management 2 (Suppl.), 235-245.

Anraku, K., Matsuda, M., Shigesato, N., Nakahara, M., \& Kawamura, G. (1998). Flounder 
show conditioned response to $200-800 \mathrm{~Hz}$ tone bursts despite their conditioning to 300 Hz tone-bursts. Nippon Suisan Gakkaishi, 64, 755-758. (in Japanese).

Astrup, J. \& Møhl, B. (1993). Detection of intense ultrasound by the cod Gadus morhua. Journal of Experimental Biology, 182, 71-80.

Astrup, J. \& Møhl, B. (1998). Discrimination between high and low repetition rates of ultrasonic pulses by the cod. Journal of Fish Biology, 52, 205-208.

Barlow, J. \& Cameron, G. A. (2003). Field experiments show that acoustic pingers reduce marine mammal bycatch in the California drift gill net fishery. Marine Mammal Science, 19, 265-283.

Buerkle, U. (1967). An audiogram, of the Atlantic cod, Gadus morhua L, Journal of the Fisheries Research Board of Canada, 24, 2309-2319.

Blaxter, J.H.S., \& Hoss, D.E. (1981). Startle response in herring: the effect of sound stimulus frequency, size of fish, and selective interference with the acoustico-lateralis system. Journal of the Marine Biology Association U.K., 61, 871-879.

Blaxter, J.H.S., Gray, J.A.B., \& Denton, E.J. (1981). Sound and startle response in herring shoals. Journal of the Marine Biology Association U.K., 61, 851-869.

Chapman, C.J., \& Hawkins, A.D. (1973). A field study of the hearing in cod, Gadus morhua L. Journal of Comparative Physiology, 85, 147-167.

Culik, B.M., Koschinski, S., Treganza, N. \& Ellis, G.M. (2001). Reactions of harbor porpoises Phocoena phocoena and herring Clupea harengus to acoustic alarms. Marine Ecological Progress Series, 211, 255-260.

Dunning, D.J., Ross, Q.E., Geoghegan, P., Reichle, J.J., Menezes, J.K. \& Watson, J.K. (1992). Alewives avoid high-frequency sound. Journal of Fisheries Management, 12, 407-416.

Engås, A., Løkkeborg, S., Ona, E. \& Soldal, A.V. (1996). Effects of seismic shooting on local abundance and catch rates of cod (Gadus morhua) and haddock (Melanogrammus aeglefinus). Canadian Journal of Fisheries and Aquatic Sciences, 53, 2238-2249.

Enger, P.S. (1967). Hearing in herring. Comparative Biochemistry and Physiology, 22, 527-538.

Enger, P.S., \& Andersen, R. (1967). An electrophysiological field study of hearing in fish. Comparative Biochemistry and Physiology, 22, 517-525.

Enger, P.S., Karlsen, H.E., Knudsen, F.R. \& Sand, O. (1993). Detection and reaction of fish to infrasound. ICES (Int. Counc. Explor. Sea) Marine Science Symposium, 196, 108-112.

Fernandes, P.G., Brierley, A.S., Simmons, E.J., Millard, N.W., McPhail, S.D. Amstrong, F., Stevenson, P., \& Squires, M. (2000). Fish do not avoid survey vessels. Nature (London), 404, 35-36.

Finneran, J.J., Oliver, Ch. W., Schaefer, K.M., \& Ridgway, S.H. (2000). Source levels and estimated yellowfin tuna (Thunnus albacares) detection ranges for dolphin pops, breaches and tail slaps. Journal Acoustical Society of America, 107, 649-656.

Fuiman, L.A., Smith, M.E., \& Malley, V.N. (1999). Ontogeny of routine swimming speed and startle responses in red drum, with a comparison of responses to acoustic and visual stimuli. Journal Fish Biology, 55, 215-226.

Gearin, P.J., Gosho, M.E., Laake, J.L.,Cooke, L., DeLong, R.L., \& Hughes, K.M. (2000). Experimental testing of acoustic alarms (pingers) to reduce bycatch of harbour porpoise, Phocoena phocoena, in the state of Washington. Journal of Cetacean Research and Management, 2, 1-9.

Hawkins, A.D. (1981). The hearing abilities of fish. In W.N. Tavolga, A.N. Popper \& R.R. Fay (Eds), Hearing and Sound Communication in Fishes (pp.109-133). New York: 
Springer-Verlag.

Hawkins, A.D. (1986). Underwater sound and fish behavior. In T.J. Pitcher (Ed.), The

Behaviour of Teleost Fishes (pp. 114-151). London: Croom Helm.

Hughes, K.M., Lehman, L.L., Gearin, P.J., Laake, J. L., DeLong, R.L. \& Gosho, M.E. (1999). Acoustic alarms and Pacific herring (Clupea pallasi). International Whaling Commission SC, 51, SM14.

Kastelein, R.A., Goodson, A.D., Lien, J. \& de Haan, D. (1995). The effects of acoustic alarms on Harbour porpoise (Phocoena phocoena) behaviour. In P.E. Nachtigall, J. Lien, W.W.L. Au, \& A.J. Read (Eds), Harbour porpoises, laboratory studies to reduce bycatch (pp. 157-167). Woerden, The Netherlands: De Spil Publishers.

Kastelein, R.A., Haan, D. de, Goodson, A.D., Staal, C. \& Vaughan, N. (1997). The effects of various sounds on a harbour porpoise (Phocoena phocoena). In A.J. Read, P.R. Wiepkema \& P.E. Nachtigall (Eds), The Biology of the Harbour porpoise (pp. 367383). Woerden, The Netherlands: De Spil Publishers.

Kastelein, R.A., Rippe, H.T., Vaughan, N., Schooneman, N.M., Verboom, W.C. \& de Haan, D. (2000). The effect of acoustic alarms on the behavior of harbor porpoises (Phocoena phocoena) in a floating pen. Marine Mammal Science, 16, 46-64.

Kastelein, R.A., de Haan, D., Vaughan, N., Staal, C. \& Schooneman, N.M. (2001). The influence of three acoustic alarms on the behaviour of harbour porpoises (Phocoena phocoena) in a floating pen. Marine Environmental Research, 52, 351-371.

Knudsen, F.R., Enger, P.S. \& Sand, O. (1994). Avoidance responses to low frequency sound in downstream migrating Atlantic salmon smolt, Salmo salar. Journal of Fish Biology, 45, 227-233.

Kraus, S., Read, A. J., Solow, A., Baldwin, K, Spradlin, T., Williamson, J. \& Anderson, E. (1997). Acoustic alarms reduce porpoise mortality. Nature, 388, 525.

Kraus, S. \& Brault, S. (1999). A springtime field test of the use of pingers to reduce incidental mortality of harbor porpoise in gill nets. International Whaling Commission SC/51, SM WP 10.

Laake, J., Rugh, D. \& Baraff, L. (1998). Observations of Harbor Porpoise in the Vicinity of Acoustic Alarms on a Set Gill Net. NOAA Technical memorandum NMFS-AFSC-84. U.S. Dept. of Commerce. 40 pp.

Lagardère, J.P., Bégout, M.L., Lafaye, J.Y., \& Villotte, J.P. (1994). Influence of windproduced noise on orientation in the sole (Solea solea). Canadian Journal of Fisheries and Aquatic Sciences, 51, 1258-1264.

Lewison, R.L., Crowder, L.B., Read, A.J., \& Freeman, S.A. (2004). Understanding impacts of fisheries bycatch on marine megafauna. Trends in Ecology and Evolution, 19, 598604.

Lien, J., Hood, C., Pittman, D, Ruel, P, Borggaard, D., Chisholm, C., Wiesner, L., Mahon, T., \& Mitchell, D. (1995). Field tests of acoustic devices on groundfish gillnets: assessment of effectiveness in reducing harbour porpoise by-catch. In R.A. Kastelein, J.A. Thomas \& P.E. Nachtigall (Eds), Sensory Systems of Aquatic Mammals (349364). Woerden, The Netherlands: De Spil Publishers.

Løkkeborg, S. \& Søldal, A.V. (1993). The influence of seismic exploration with airguns on cod Gadus morhua behaviour and catch rates. ICES (Int. Counc. Explor. Sea) Marine Science Symposium, 196, 62-67.

Luczkovich, J.J., Daniel III, H.J., Hutchinson, M., Jenkins, T., Johnson, S.E., Pullinger, C., \& Sprague, M.W. (2000). Sounds of sex and death in the sea: bottlenose dolphin whistles suppress mating choruses of silver perch. Bioacoustics, 10, 323-334,

Mann, D.A., Lu, Z., \& Popper, A. (1997). A clupeid fish can detect ultrasound. Nature, 389, 341 . 
Mann, D. A., Higgs, D. M., Tavolga, W. N., Souza, M. J., \& Popper, A. N. (2001). Ultrasound detection by clupeiform fishes. Journal of the Acoustical Society of America, 109, 3048-3054.

Mann, D. A., Lu, Z., Hastings, M. C. \& Popper, A. N. (1998). Detection of ultrasonic tones and simulated dolphin echolocation clicks by a teleost fish, the American shad (Alosa sapidissima). Journal of the Acoustical Society of America, 104, 562-568.

Mann, D.A., Lu, Z., \& Popper, A.N. (1997). Ultrasound detection by a teleost fish. Nature 389, 341.

Mann, D.A., Popper, A.N., \& Wilson, B. (2005). Herring do not detect ultrasound. Proceedings of the Royal Society of London Biological Letters 1, 158-161.

Misund, O.A. (1990). Sonar observations of schooling herring: school dimensions, swimming behaviour, and avoidance of vessel and purse seine. Rapport Par-v.

Réunion Conseil International pour l'Exploration de la Mer, 189,135-146.

Misund, O.A. \& Aglen (1992). Swimming behaviour of fish schools in the North Sea during acoustic surveying and pelagic trawl sampling. ICES Journal of Marine Science, 49, 325-334.

Misund, O.A., Øvredal, J.T., \& Hafsteinsson, M.T. (1996). Reactions of herring schools to the sound field of a survey vessel. Aquatic Living Resources, 9, 511.

Motomatsu, K., Hiraishi, T., Yamamoto, K., \& Nashimoto, K. (1998). Auditory masking by ambient noise in black rockfish Sebastes schlegeli. Nippon Suisan Gakkaishi, 64, 792795.

Moulton, J.M., \& Backus, R.H. (1955). Annotated references concerning the effects of manmade sounds on the movements of fishes. Fish. Circ. Dep. Seashore Fish. 17, 1-8.

Nedwell, J.R., Edwards, B., Turnpenny, A.W.H., \& Gordon, J. (2004). Fish and Marine Audiograms: a summary of available information. Subacoustech report ref. 534R0214. September 2004.

Nestler, J.M., Ploskey, G.R., \& Pickens, J. (1992). Responses of Blueback Herring to HighFrequency Sound and Implications for Reducing Entrainment at Hydropower Dams. Journal of Fisheries Management, 12, 667-683.

Offutt, G.C. (1974). Structures for the detection of acoustic stimuli in the Atlantic codfish, Gadus morhua. Journal of the Acoustical Society of America, 56, 665-671.

Pearson, W.H., Skalski, J.R., \& Malme, C.I. (1992). Effects of sound from a geophysical survey device on behaviour of captive rockfish (Sebastes spp.). Canadian Journal of Fisheries and Aquatic Sciences, 49, 1343-1356.

Popper, A. N., \& Carlson, T. J. (1998). Application of the use of sound to control fish behavior. Transactions of the American Fisheries Society, 127, 673-707.

Ryan, B.F., \& Joiner, B.L. (1994). Minitab handbook (3rd edition). Belmont, California; Duxbury Press.

Read, A. J., Drinker, P., \& Northridge, S. (2006). Bycatch of marine mammals in U.S. and global fisheries. Conservation Biology, 20, 163-169.

Richardson, W.J., Greene, Ch. R., Malme, Ch. I., \& Thomson, D.H. (1995). Marine

Mammals and Noise. London: Academic Press, Inc.

Rossi, L., \& Rossi, J.L. (2005). Frequency modulation of the sounds produced by AQUAmark 200® deterrent devices. Acoustic Research Letters Online, 6, 20-24.

Skalski, J.R., Pearson, W.H, \& Malme, C.I. (1992). Effects of sound from a geophysical survey device on catch-per-unit-effort in the hook-and-line fisheries for rockfish (Sebastes spp.). Canadian Journal of Fisheries and Aquatic Sciences, 49, 1357-1365.

Schwarz, A.L., \& Greer, G.L. (1984). Responses of Pacific herring, Clupea harengus 
pallasi, to some underwater sounds. Canadian Journal of Fisheries and Aquatic Sciences, 41, 1183-1192.

Trippel, E.A., Strong, M.B., Terhune, J. M., \& Conway, J.D. (1999). Mitigation of harbour porpoise (Phocoena phocoena) by-catch in the gillnet fishery in the lower Bay of Fundy. Canadian Journal of Fisheries and Aquatic Sciences, 56, 113-123.

Wahlberg, M., \& Westerberg, H. (2005). Hearing in fish and their reactions to sounds from offshore wind farms. Marine Ecology Progress Series, 288, 295-309.

Wilson, B., \& Dill, L.M. (2002). Pacific herring respond to simulated odontocete echolocation sounds. Canadian Journal of Fisheries and Aquatic Sciences, 59, $542-553$.

Zar, J.H. (1984). Biostatistical analysis. (2 ${ }^{\text {nd }}$ edition). Prentice Hall, Englewood Cliffs, NY. 
Tables:

Table 1. Review of studies on the effects of pingers on fish catches and behaviour of captive marine fish.

\begin{tabular}{|c|c|c|c|c|c|c|}
\hline $\begin{array}{l}\text { Pinger } \\
\text { make and } \\
\text { model }\end{array}$ & $\begin{array}{l}\text { Pinger } \\
\text { spectrum }\end{array}$ & $\begin{array}{l}\text { Pinger } \\
\text { SL (dB } \\
\text { re } 1 \\
\mu \mathrm{Pa} @ \\
1 \mathrm{~m})\end{array}$ & Target fish species & $\begin{array}{l}\text { Effect on } \\
\text { target fish } \\
\text { catch }\end{array}$ & $\begin{array}{l}\text { Effect on } \\
\text { behaviou } \\
r \text { of } \\
\text { captive } \\
\text { fish } \\
\end{array}$ & Source \\
\hline $\begin{array}{l}\text { Dukane } \\
\text { NetMark } \\
1000 \text { with } \\
\text { saltwater } \\
\text { switch } \\
\end{array}$ & $\begin{array}{l}0.3 \text {-s broad- } \\
\text { band signal } \\
\text { centred at } \\
10 \mathrm{kHz} \text { every } \\
4 \mathrm{~s}\end{array}$ & 132 & Atlantic herring & $\begin{array}{l}\text { Reduction } \\
\text { catch rate }\end{array}$ & -- & $\begin{array}{l}\text { Kraus et } \\
\text { al., } \\
1997\end{array}$ \\
\hline $\begin{array}{l}\text { Dukane } \\
\text { NetMark } \\
1000\end{array}$ & $\begin{array}{l}0.3 \text {-s broad- } \\
\text { band signal } \\
\text { centred at } \\
10 \mathrm{kHz} \text { every } \\
4 \mathrm{~s}\end{array}$ & 132 & $\begin{array}{l}\text { Cod (Gadus } \\
\text { morhua) and } \\
\text { Pollock (Pollachius } \\
\text { virens). }\end{array}$ & $\begin{array}{l}\text { No effect } \\
\text { on catch } \\
\text { rate }\end{array}$ & - & $\begin{array}{l}\text { Kraus } \\
\text { and } \\
\text { Brault, } \\
1999\end{array}$ \\
\hline $\begin{array}{l}\text { Home- } \\
\text { made }\end{array}$ & $\begin{array}{l}\text { Broad-band } \\
\text { signal with } \\
\text { peaks at } 3 \text { and } \\
20 \mathrm{kHz}\end{array}$ & $121-125$ & $\begin{array}{l}\text { Chinook salmon } \\
\text { (Oncorhynchus } \\
\text { tshawytscha) and } \\
\text { sturgeon (Acipenser } \\
\text { sp.) }\end{array}$ & $\begin{array}{l}\text { No effect } \\
\text { on catch } \\
\text { rate }\end{array}$ & -- & $\begin{array}{l}\text { Gearin } \\
\text { et al., } \\
2000\end{array}$ \\
\hline $\begin{array}{l}\text { Home } \\
\text { made }\end{array}$ & $\begin{array}{l}\text { Broadband } \\
\text { signal with } \\
\text { peaks at } 3 \text { and } \\
20 \mathrm{kHz}\end{array}$ & $121-125$ & $\begin{array}{l}\text { Pacific herring } \\
\text { (Clupea pallasi) }\end{array}$ & $\begin{array}{l}\text { No effect } \\
\text { on catch } \\
\text { rate }\end{array}$ & $\begin{array}{l}\text { No effect } \\
\text { on } \\
\text { behaviour } \\
\text { in net pen } \\
\end{array}$ & $\begin{array}{l}\text { Hughes } \\
\text { et al., } \\
1999\end{array}$ \\
\hline $\begin{array}{l}\text { Dukane, } \\
\text { NetMark } \\
1000\end{array}$ & $\begin{array}{l}0.3-\mathrm{s} \text { pulse at } \\
10-12 \mathrm{kHz} \\
\text { every } 4 \mathrm{~s}\end{array}$ & $133-145$ & $\begin{array}{l}\text { Atlantic herring } \\
\text { (Clupea harengus), } \\
\text { Atlantic cod (Gadus } \\
\text { morhua), and } \\
\text { pollock (Pollachius } \\
\text { virens) }\end{array}$ & $\begin{array}{l}\text { No effect } \\
\text { on catch } \\
\text { rate }\end{array}$ & -- & $\begin{array}{l}\text { Trippel } \\
\text { et al., } \\
1999\end{array}$ \\
\hline $\begin{array}{l}\text { Dukane, } \\
\text { NetMark } \\
1000 \\
\& \\
\text { Lien } \\
\& \\
\text { PICE }\end{array}$ & $\begin{array}{l}0.3-\mathrm{s} \text { pulse at } \\
10-12 \mathrm{kHz} \\
\text { every } 4 \mathrm{~s} \\
\& \\
4 \mathrm{kHz} \\
\& \\
55-100 \mathrm{kHz} \\
\text { sweeps }\end{array}$ & $\begin{array}{l}132 \\
\\
\& \\
135 \\
\& \\
95-145\end{array}$ & $\begin{array}{l}\text { Atlantic herring } \\
\text { (Clupea harengus) }\end{array}$ & $\begin{array}{l}\text { No effect } \\
\text { on catch } \\
\text { rate. }\end{array}$ & -- & $\begin{array}{l}\text { Culik et } \\
\text { al., } \\
2001\end{array}$ \\
\hline $\begin{array}{l}\text { Dukane } \\
\text { NetMark } \\
1000\end{array}$ & $\begin{array}{l}0.3-\mathrm{s} \text { pulse at } \\
10-11 \mathrm{kHz} \\
\text { every } 4 \mathrm{~s}\end{array}$ & $133-145$ & $\begin{array}{l}\text { Pacific herring } \\
\text { (Clupea pallassii) }\end{array}$ & & $\begin{array}{l}\text { No effect } \\
\text { on } \\
\text { behaviour } \\
\text { in tank }\end{array}$ & $\begin{array}{l}\text { Wilson } \\
\text { and } \\
\text { Dill, } \\
2002\end{array}$ \\
\hline
\end{tabular}


Table 2. Mean standard body length and weight of the five fish species which were subjected to sounds. The length and weight of the herring were estimated as this species could not be handled without causing injury to the fish. $\mathrm{N}=$ number of individuals, $\mathrm{SD}=$ standard deviation.

\begin{tabular}{|c|c|c|c|c|c|c|c|}
\hline Species & $\mathbf{N}$ & \multicolumn{3}{|c|}{ Standard body length $(\mathrm{cm})$} & \multicolumn{3}{|c|}{ Body weight (g) } \\
\hline & & Mean & SD & Range & Mean & SD & Range \\
\hline Sea bass & 10 & 25 & 4 & $20-30$ & 209 & 69 & $86-332$ \\
\hline Pout & 12 & 21 & 1 & $18-23$ & 117 & 27 & 84-172 \\
\hline $\begin{array}{c}\text { Thicklip } \\
\text { mullet }\end{array}$ & 10 & 17 & 3 & $14-21$ & 57 & 29 & $24-91$ \\
\hline Herring & 13 & 20 & 4 & $15-25$ & 75 & 4 & $70-80$ \\
\hline Cod & 9 & 31 & 2 & $27-33$ & 315 & 54 & $217-377$ \\
\hline
\end{tabular}

Table 3. Water temperature during the test periods for the five fish species. $\mathrm{N}=$ number of measurements, $\mathrm{SD}=$ standard deviation.

\begin{tabular}{|c|c|c|c|c|}
\hline Fish species & $\begin{array}{c}\text { Mean water } \\
\text { Temperature }\left({ }^{\circ} \mathbf{C}\right)\end{array}$ & SD & $\mathbf{N}$ & Range \\
\hline Sea bass & 7.8 & 2.2 & 17 & $4.1-10.9$ \\
\hline Pout & 6.5 & 2.5 & 83 & $4.0-12.0$ \\
\hline $\begin{array}{c}\text { Thicklip } \\
\text { mullet }\end{array}$ & 9.2 & 1.7 & 88 & $4.0-11.0$ \\
\hline Herring & 13.7 & 1.0 & 88 & $11.0-16.0$ \\
\hline Cod & 15.8 & 1.1 & 88 & $14.0-18.0$ \\
\hline
\end{tabular}


Table 4. Description of the two 'known effect' reference sounds and the signals of seven commercially available pingers that were tested on North Sea fish species. The Source Levels (SLs) of the 'known effect' reference sounds and pinger signals were measured with the hydrophone $1 \mathrm{~m}$ from the transducer or pinger, the Sound Pressure Levels (SPLs) with the hydrophone $6 \mathrm{~m}$ from the transducer or pinger. The calculations of $\mathrm{SL}_{\text {pulse }}$ and $\mathrm{SL}_{\text {cycle }}$ are described in section 2.4. For randomized signals the $\mathrm{SL}_{\text {cycle }}$ is calculated over the shortest (Min), average (Avg), and longest (Max) signal interval. 


\begin{tabular}{|c|c|c|c|c|c|c|c|}
\hline $\begin{array}{l}\text { Sound source and } \\
\text { manufacturer }\end{array}$ & $\begin{array}{l}\text { Signal } \\
\text { type }\end{array}$ & $\begin{array}{c}\text { Signal } \\
\text { duration } \\
(\mathrm{ms})\end{array}$ & $\begin{array}{c}\text { Signal } \\
\text { interval } \\
(\mathbf{s})\end{array}$ & $\begin{array}{c}\text { SL }_{\text {pulse }} \\
\text { (dB re 1 } \\
\mu P a @ \\
1 \text { m) }\end{array}$ & $\begin{array}{c}\mathrm{SL}_{\text {cycle }} \\
\text { (dB re } \\
1 \mu \mathrm{Pa} @ \\
1 \mathrm{~m}) \\
\end{array}$ & $\begin{array}{c}\text { SPL } \\
@ 6 \mathrm{~m} \\
(\mathrm{~dB} \text { re } \\
1 \mu \mathrm{Pa})\end{array}$ & $\begin{array}{c}\text { Frequency spectrum and } \\
\text { peak levels at } 1 \mathrm{~m} \\
(\mathrm{~dB} \text { re } 1 \mu \mathrm{Pa})\end{array}$ \\
\hline $\begin{array}{l}\text { DRS- } 8 \text { transmitter } \\
\text { by Ocean } \\
\text { Engineering } \\
\text { Enterprise } \\
\end{array}$ & $\begin{array}{l}600 \mathrm{~Hz} \text { tonal } \\
\text { 'known effect' } \\
\text { reference } \\
\text { sound } \\
\end{array}$ & 300 & 4 & 172 & 161 & 177 & \\
\hline $\begin{array}{l}\text { DRS- } 8 \text { transmitter } \\
\text { by Ocean } \\
\text { Engineering } \\
\text { Enterprise } \\
\end{array}$ & $\begin{array}{l}3 \mathrm{kHz} \text { tonal } \\
\text { 'known effect' } \\
\text { reference } \\
\text { sound } \\
\end{array}$ & 300 & 4 & 202 & - & - & \\
\hline $\begin{array}{c}\text { Fumunda } \\
\text { FMDP } 2000 \\
\text { by } \\
\text { Fumunda Marine } \\
\text { Products, USA }\end{array}$ & $\begin{array}{l}\text { Tonal signal } \\
9.6 \mathrm{kHz}\end{array}$ & 297 & 3.2 & 141 & 131 & 138 & $\begin{array}{l}\text { Harmonic energy up to } 73 \\
\mathrm{kHz}, 3^{\text {rd }} \text { and } 5^{\text {th }} \text { harmonic } \\
-10 \mathrm{~dB} \cdot 0.02-0.1 \mathrm{kHz}-60 \\
\mathrm{~dB} .\end{array}$ \\
\hline $\begin{array}{c}\text { Airmar gillnet pinger } \\
\text { by AIRMAR } \\
\text { Technology } \\
\text { Corporation, USA }\end{array}$ & $\begin{array}{c}\text { Tonal signal } \\
9.8 \mathrm{kHz}\end{array}$ & 309 & 3.5 & 134 & 124 & 125 & $\begin{array}{l}\text { Harmonic energy up to } 50 \\
\mathrm{kHz}-30 \mathrm{~dB} .0 .02-0.1 \mathrm{kHz} \\
-30 \text { to }-60 \mathrm{~dB} \text {. }\end{array}$ \\
\hline $\begin{array}{l}\text { AQUAmark } 100 \\
\text { by Aquatec Subsea } \\
\text { Ltd, UK }\end{array}$ & $\begin{array}{l}\text { Tonal } \\
\text { and sweep } \\
\text { signals }\end{array}$ & $\begin{array}{l}\text { Random } \\
\text { Avg } 304 \\
\text { Min } 213 \\
\text { Max } 358\end{array}$ & \begin{tabular}{|c|} 
Random \\
Avg. 12.2 \\
Min. 4.2 \\
Max 22.6
\end{tabular} & $\begin{array}{c}148 \\
(\mathrm{SD} 3.7) \\
(\mathrm{n}=16)\end{array}$ & $\begin{array}{c}\text { Avg 133 } \\
\text { Min 142 } \\
\text { Max } \\
130\end{array}$ & $\begin{array}{c}143 \\
(\mathrm{SD} 1.6) \\
(\mathrm{n}=16)\end{array}$ & $\begin{array}{l}\text { Tonal levels }+7 \mathrm{~dB} \text { with } \\
\text { peaks at } 64.4 \mathrm{kHz}(136 \\
\mathrm{dB}) \text { and } 128 \mathrm{kHz}(100 \\
\mathrm{dB}) . \text { Sweep signals } \\
\text { peaked between } 44-54 \\
\mathrm{kHz} \& 60-80 \mathrm{kHz}, \mathrm{LF} \\
\text { peaks at } 0.75(-34 \mathrm{~dB}) \& \\
1.6 \mathrm{kHz}(-50 \mathrm{~dB}) .\end{array}$ \\
\hline $\begin{array}{l}\text { AQUA mark } 200^{*} \\
\text { by Aquatec Subsea } \\
\text { Ltd, UK }\end{array}$ & $\begin{array}{c}\text { Tonal } \\
\text { and sweep }\end{array}$ & $\begin{array}{l}\text { Random } \\
\text { Avg 282 } \\
\text { Min 272 } \\
\text { Max 293 }\end{array}$ & $\begin{array}{l}\text { Random } \\
\text { Avg } 12.1 \\
\text { Min } 3.7 \\
\text { Max } 21.1\end{array}$ & $\begin{array}{c}134 \\
(\mathrm{SD} 1.26) \\
(\mathrm{n}=16)\end{array}$ & $\begin{array}{l}\text { Avg 118 } \\
\text { Min 123 } \\
\text { Max 120 }\end{array}$ & $\begin{array}{c}130 \\
(\mathrm{SD} 1.5) \\
(\mathrm{n}=16)\end{array}$ & $\begin{array}{l}\text { Tonal peaks at } 21 \& 42 \\
\mathrm{kHz}(126-130 \mathrm{~dB}) \text { and } 63- \\
104 \mathrm{kHz}(-5 \text { to- } 15 \mathrm{~dB}) . \\
\text { Sweep signals peaked } \\
\text { between } 10-14 \mathrm{kHz} \& 48- \\
53 \mathrm{kHz} \text {. LF peaks at } 0.7 \\
\mathrm{kHz}(-15 \mathrm{~dB}) .\end{array}$ \\
\hline $\begin{array}{c}\text { SaveWave } \\
\text { endurance } \\
\text { by SaveWave BV, } \\
\text { The Netherlands }\end{array}$ & $\begin{array}{l}\text { veep } \\
\text { gnal }\end{array}$ & $\begin{array}{l}\text { Random } \\
\text { Avg. 295 } \\
\text { Min. 196 } \\
\text { Max. 393 }\end{array}$ & $\begin{array}{l}\text { Random } \\
\text { Avg } 14.5 \\
\text { Min } 8.2 \\
\text { Max 21.1 }\end{array}$ & $\begin{array}{c}134 \\
(\mathrm{SD} 0.41) \\
(\mathrm{n}=14)\end{array}$ & $\begin{array}{l}\text { Avg 117 } \\
\text { Min 117 } \\
\text { Max } 117\end{array}$ & $\begin{array}{c}132 \\
(\mathrm{SD} 0.7) \\
(\mathrm{n}=12)\end{array}$ & $\begin{array}{l}\text { Sweep } 5.3-110 \mathrm{kHz} . \\
\text { Peaks between } 7-95 \mathrm{kHz} \\
112-116 \mathrm{~dB} \text {. } \mathrm{LF} \\
\text { contribution } 0.5-3 \mathrm{kHz}- \\
40 \mathrm{~dB} \text {. Pulse duration } \\
\text { proportional to time } \\
\text { intervals. }\end{array}$ \\
\hline $\begin{array}{c}\text { SaveWave white } \\
\text { high impact } \\
\text { by SaveWave BV, } \\
\text { The Netherlands }\end{array}$ & $\begin{array}{l}\text { Sweep } \\
\text { signal }\end{array}$ & $\begin{array}{l}\text { Random } \\
\text { Avg. 529 } \\
\text { Min. } 197 \\
\text { Max. } 852\end{array}$ & \begin{tabular}{|c|} 
Random \\
Avg. 11.39 \\
Min. 2.65 \\
Max. \\
18.24 \\
\end{tabular} & $\begin{array}{c}140 \\
(\mathrm{SD} 0.58) \\
(\mathrm{n}=17)\end{array}$ & $\begin{array}{l}\text { Avg 126 } \\
\text { Min 131 } \\
\operatorname{Max} 125\end{array}$ & $\begin{array}{c}141 \\
(\mathrm{SD} 0.43) \\
(\mathrm{n}=17)\end{array}$ & $\begin{array}{l}\text { Sweep 5-95 kHz } 115 \mathrm{~dB} \text {. } \\
\text { Peaks between } 7.5-54 \\
\text { kHz }+12 \mathrm{~dB} \text {. LF } \\
\text { contribution } 0.75-2.4 \mathrm{kHz} \\
-20 /-35 \mathrm{~dB} \text {. }\end{array}$ \\
\hline $\begin{array}{l}\text { SaveWave black } \\
\text { high impact } \\
\text { by SaveWave BV, } \\
\text { The Netherlands }\end{array}$ & $\begin{array}{c}\text { Sweep } \\
\text { signal }\end{array}$ & $\begin{array}{l}\text { Random } \\
\text { Avg. } 318 \\
\text { Min. } 229 \\
\text { Max. } 427\end{array}$ & $\begin{array}{l}\text { Random } \\
\text { Avg } 14.6 \\
\text { Min } 8.8 \\
\text { Max } 23.0\end{array}$ & $\begin{array}{c}143 \\
(\mathrm{SD} 0.67) \\
(\mathrm{n}=13)\end{array}$ & $\begin{array}{l}\text { Avg 127 } \\
\text { Min 127 } \\
\text { Max 126 }\end{array}$ & $\begin{array}{c}143 \\
(\mathrm{SD} 1.0) \\
(\mathrm{n}=12)\end{array}$ & $\begin{array}{l}\text { Sweep } 33-97 \mathrm{kHz} 108 \\
\mathrm{~dB}, \text { Peaks between } 50-95 \\
\mathrm{kHz}(+10 \mathrm{~dB}) \text {. LF } \\
\text { contribution } 6 \text { to } 9 \mathrm{kHz}- \\
40 \mathrm{~dB} \text {. }\end{array}$ \\
\hline
\end{tabular}

* For a detailed description of the signals of the AQUAmark 200, see Rossi and Rossi (2005). 
Table 5. The general behaviour of the five fish species used in the present study.

\begin{tabular}{|l|l|l|l|l|}
\hline $\begin{array}{l}\text { Fish } \\
\text { species }\end{array}$ & $\begin{array}{l}\text { Swimming } \\
\text { speed during } \\
\text { baseline } \\
\text { qualified }\end{array}$ & $\begin{array}{l}\text { Swimming speed } \\
\text { range during } \\
\text { baseline }(\mathbf{m} / \mathbf{s})\end{array}$ & $\begin{array}{l}\text { Description of school and } \\
\text { swimming behaviour }\end{array}$ & $\begin{array}{l}\text { Distance to } \\
\text { bottom (m) }\end{array}$ \\
\hline Sea bass & Relatively fast & $0.11-0.34$ & $\begin{array}{l}\text { Compact school. In large } \\
\text { ovals }\end{array}$ & $0.1-1.3$ \\
\hline Pout & $\begin{array}{l}\text { Very slow, } \\
\text { sometimes } \\
\text { stationary }\end{array}$ & $0.00-0.23$ & $\begin{array}{l}\text { Loose group. From one corner } \\
\text { to another in no particular } \\
\text { order, but usually following } \\
\text { the pool walls }\end{array}$ & $0.0-0.4$ \\
\hline $\begin{array}{l}\text { Thicklip } \\
\text { mullet }\end{array}$ & Relatively fast & $0.03-0.29$ & In a school. In ovals & $0.1-1.9$ \\
\hline Herring & Fast & $0.38-0.74$ & In a school. In large ovals & $0.1-0.3$ \\
\hline Cod & Slow & $0.16-0.27$ & $\begin{array}{l}\text { In a school. Through the tank } \\
\text { in seemingly random } \\
\text { directions }\end{array}$ & $0.1-0.9$ \\
\hline
\end{tabular}

Table 6. Results of statistical analysis of responses of fish species to pingers. Results are from paired t-tests or Wilcoxon matched pairs tests (indicated by ${ }^{\mathrm{W}}$ ), depending on the distribution of the differences of the variable values in baseline and test periods (calculated as test minus baseline, and expressed by the $\mathrm{D}$ in front of the behavioural parameter). Sample size was 11 sessions in all cases except $* n=6$ and $\dagger n=10$. ' $n s^{\prime}=$ no significant difference between baseline and test $(\alpha=0.05)$, 'increase' $=$ value is significantly higher in test than in baseline, 'decrease' = value is significantly lower in test than in baseline; exact $p$-values are shown in parentheses. The table shows the response of each species of fish to 'known effect' sounds which elicited a clear response. Cod did not respond at all to any sound produced. Variables which did not change in response to the 'known effect' audible sounds are not shown in this table. Endu $=$ endurance, w.h.i. $=$ white high impact, b.h.i. $=$ black high impact.

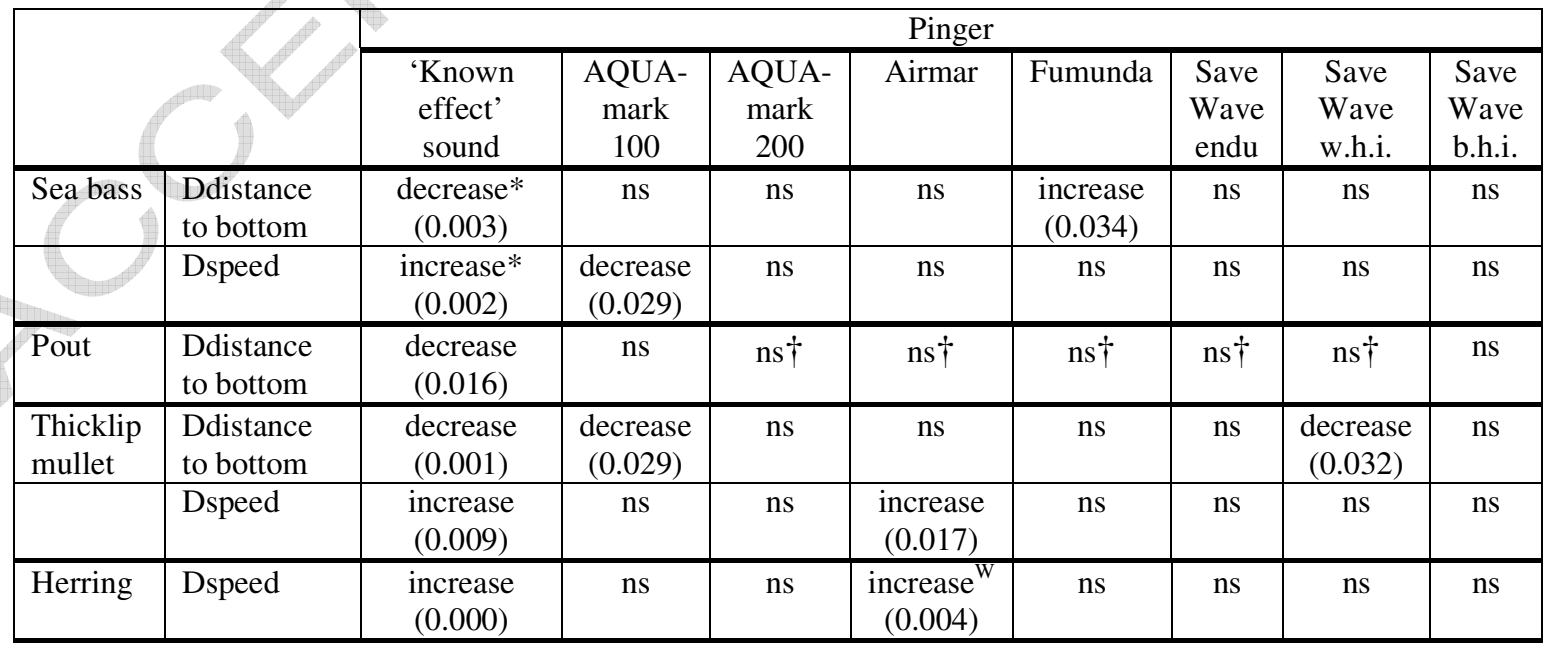




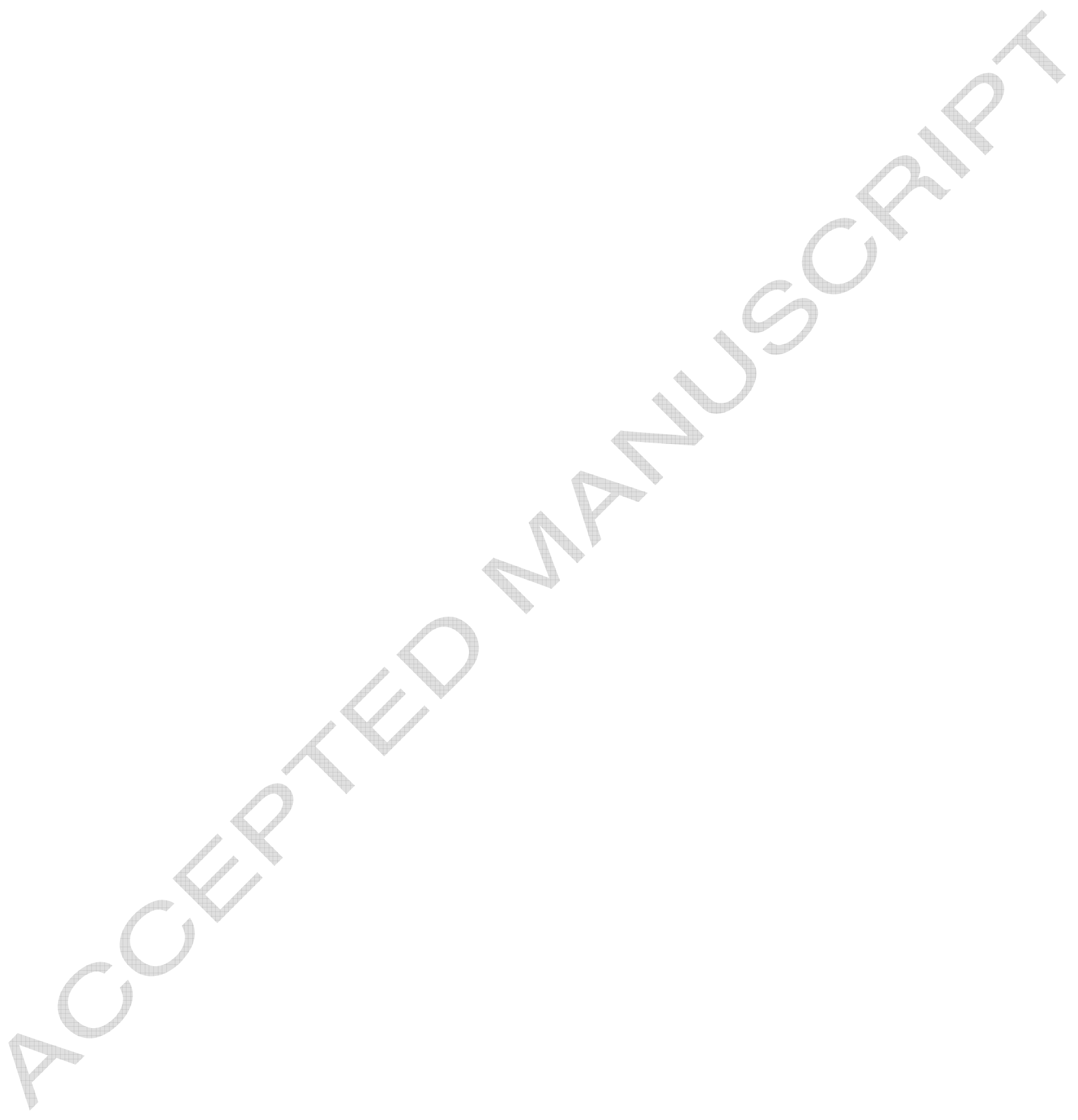


Legends to the figures:

Fig. 1. Schematic view of the study area showing the grid on the bottom and walls, the orientation of the three cameras, and the location of the transducer or pinger.

Fig. 2. Background noise limits in the pool between $20 \mathrm{~Hz}$ and $50 \mathrm{kHz}$. Each measurement was done during a 32-60 s period. Results are given as equivalent spectrum levels at $1 / 3$ octave centre frequencies ( $\mathrm{dB}$ re $1 \mu \mathrm{Pa} / \sqrt{\mathrm{Hz}}$ ), and as $1 / 3$-octave band levels ( $\mathrm{dB}$ re $1 \mu \mathrm{Pa}$ ). SPL signifies Sound Pressure Level.

Fig. 3. Differences in behavioural parameters, calculated as mean test value minus mean baseline value, for each session. Only behavioural parameters which differed significantly from zero are shown (see Table 6). A. Sea bass decreased their speed in response to the AQUAmark100; B. Sea bass swam closer to the surface in response to the Fumunda; C. Thicklip mullet swam closer to the bottom in response to the AQUAmark 100; D. Thicklip mullet increased their swimming speed in response to the Airmar; E. Thicklip mullet swam closer to the bottom in response to the SaveWave white high impact; F. Herring increased their swimming speed in response to the Airmar. 


\section{ACCEPTED MANUSCRIPT}

Pinger - Fish

Figure 1

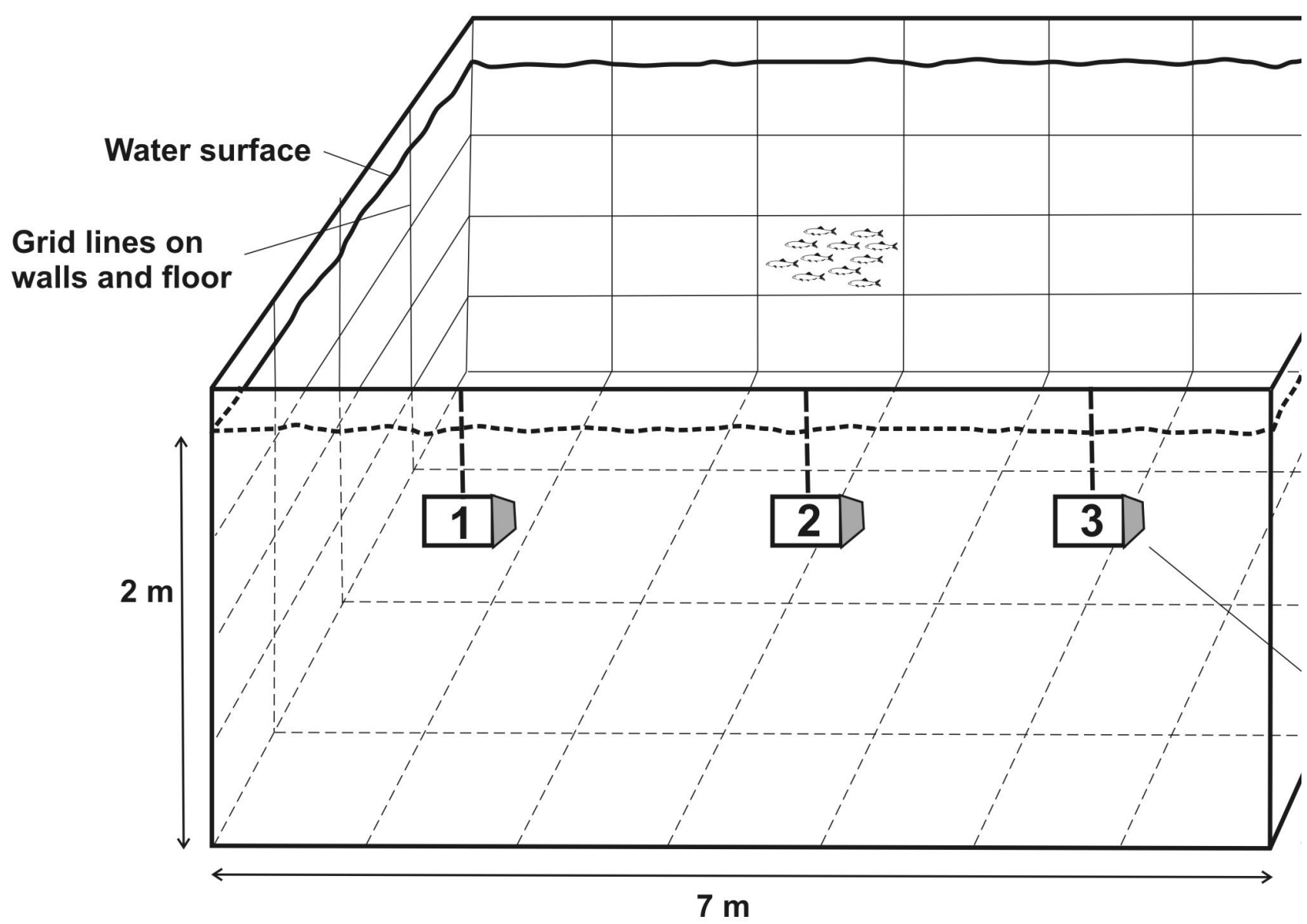

Pinger-Fish

1-12-2006/10:42

Figure 2 


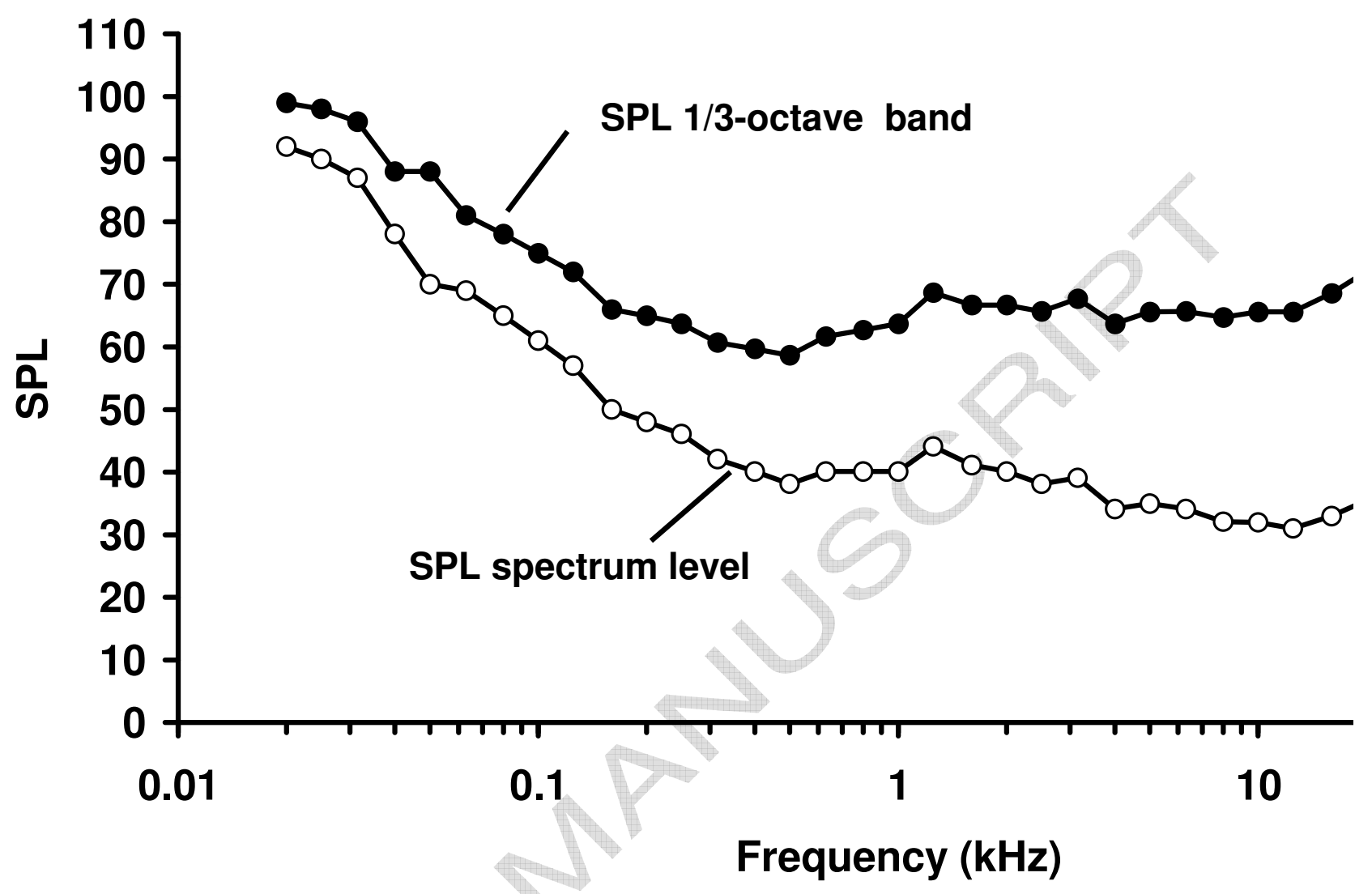




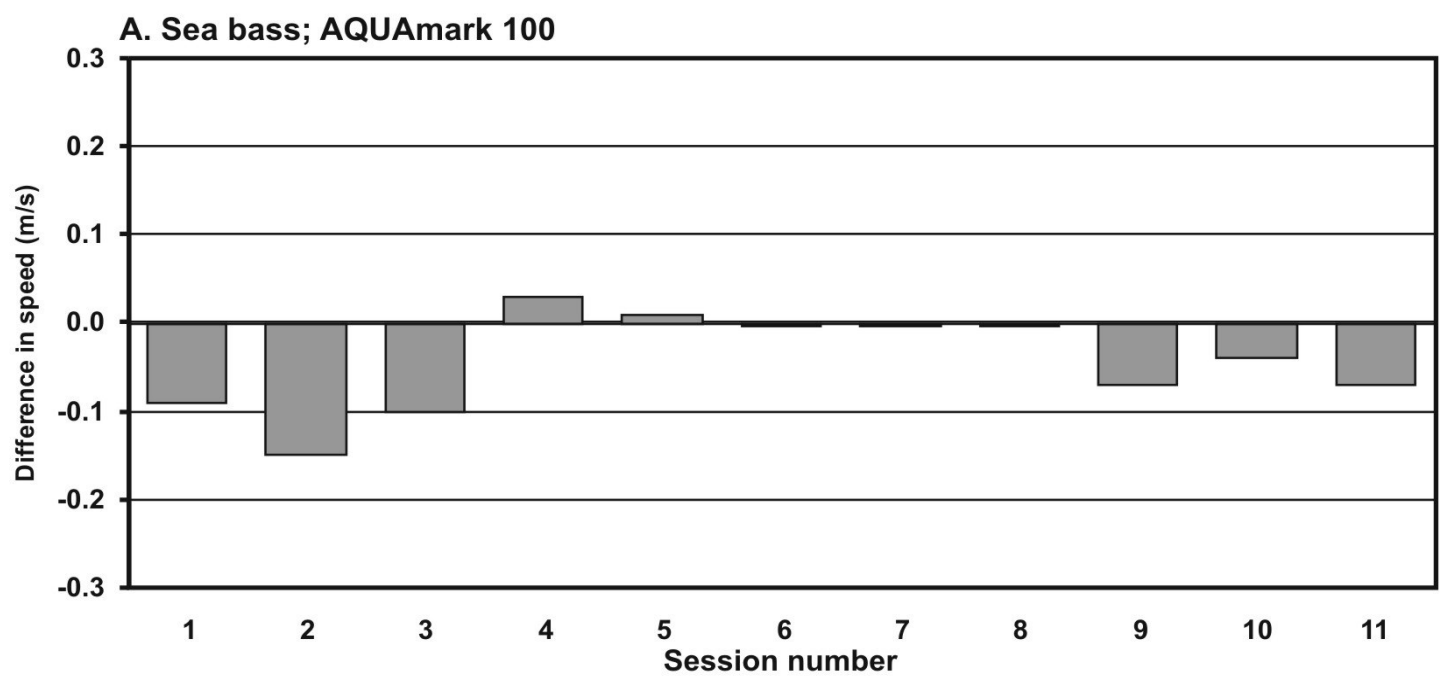

B. Sea bass; Fumunda

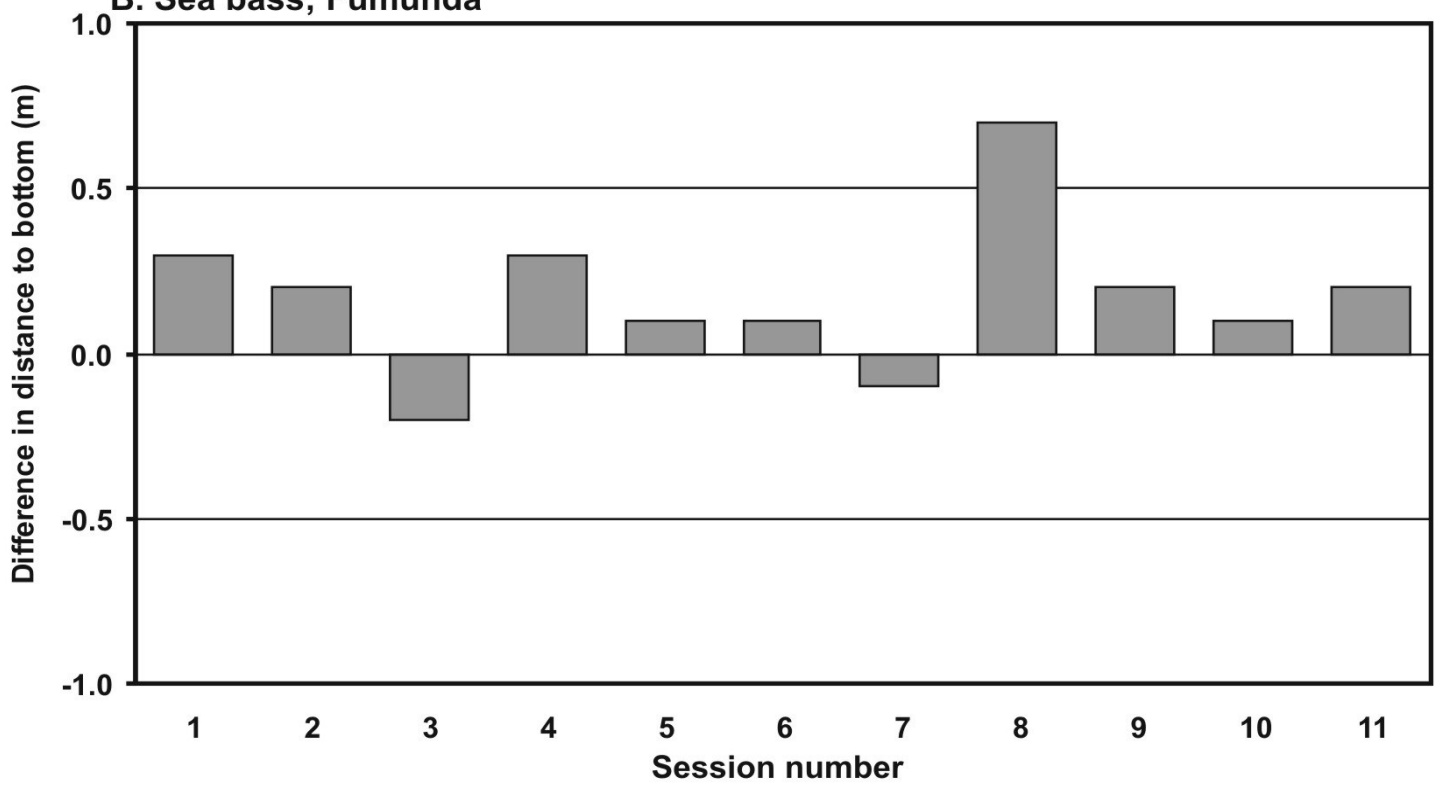

C. Thicklip mullet; AQUAmark 100

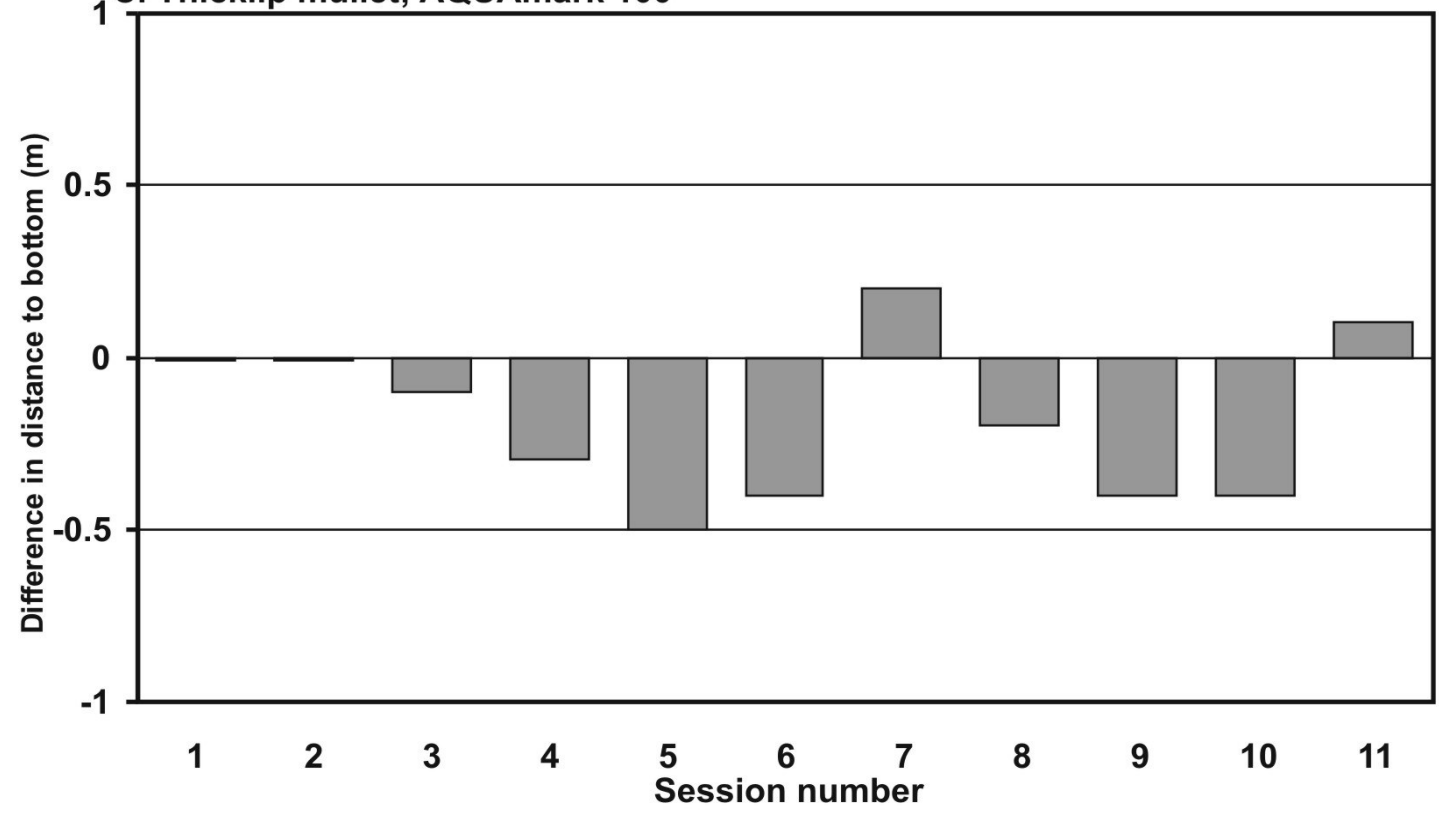



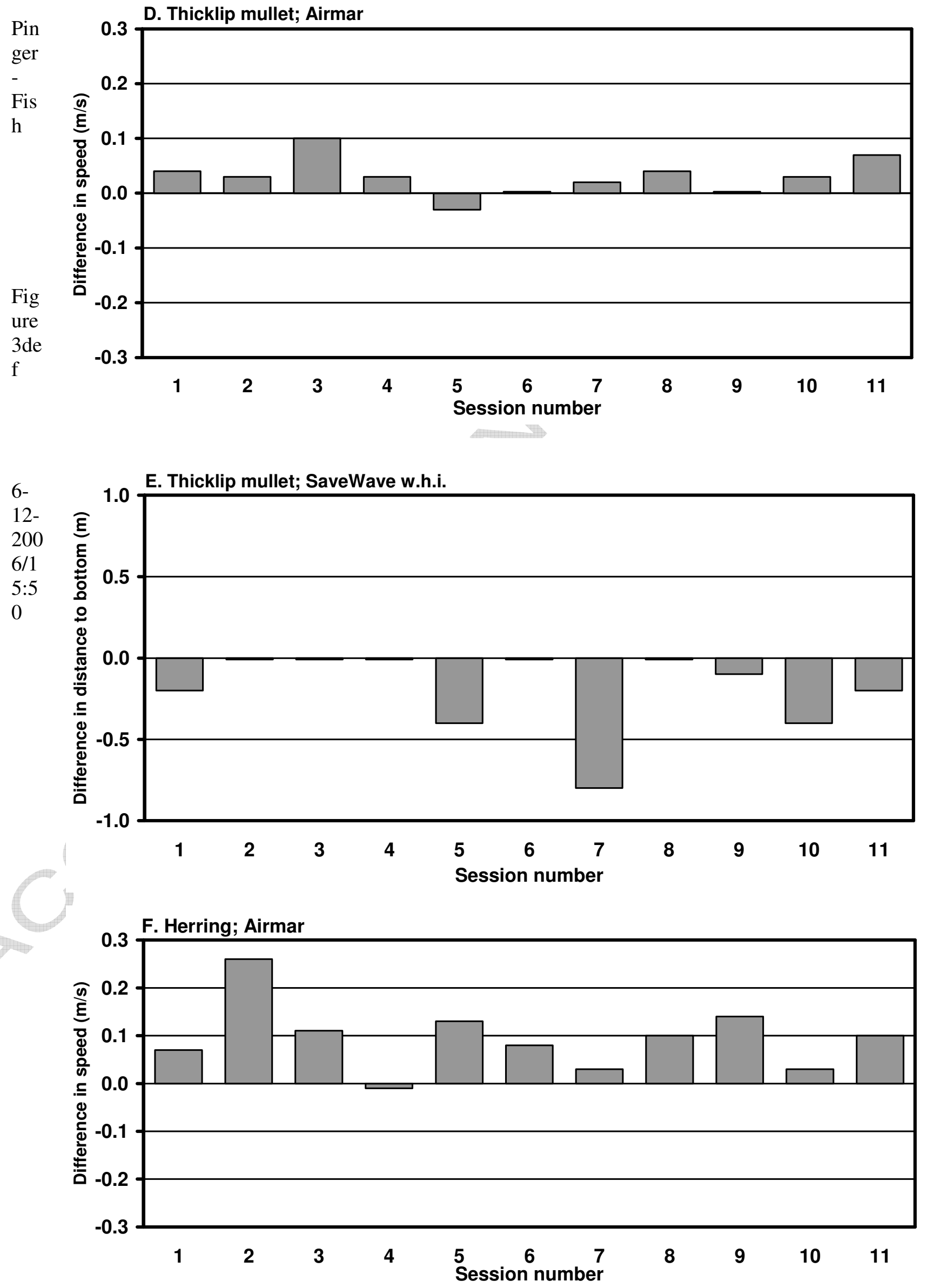